\title{
Host-selection behavior of nymphs of Vanduzeea arquata and Enchenopa binotata Discrimination of whole twigs, leaf extracts and sap exudates
}

\author{
Agnes Kiss \\ Division of Biological Sciences, University of Michigan, Ann Arbor, MI48109; Present address: \\ Agricultural Production Division, Room 413 SA-18, Office of Agriculture, Bureau for Science and \\ Technology, Agency for International Development, Washington, DC 20523, USA
}

Keywords: host-discrimination, Homoptera, Membracidae, Vanduzeea arquata, Enchenopa binotata, secondary compounds, alkaloids, phloem sap, hop-tree Ptelea trifoliata

\section{Abstract}

The host-discrimination behavior of two species of phloem-feeding membracid nymphs was examined through pair-wise choice experiments using whole twigs, leaf extracts and sap exudates. Both species have restricted host ranges in the field: Vanduzeea arquata is monophagous, while Enchenopa binotata may best be considered narrowly oligophagous in that it represents a complex of sympatric, reproductively isolated populations each associated with a different species or genus of plants.

Nymphs of both species settled preferentially on twigs of their respective host plants but those of $V$. arquata showed absolute discrimination while those of $E$. binotata selected the alternative twigs a small percentage of the time. Vanduzeea arquata nymphs also showed a greater sensitivity to plant extracts, as a larger proportion of their responses, both positive and negative, were significant. Leaf extracts of all plants tested discouraged ingestion but not probing, and most nymphs exhibited a positive probing response to the extracts of their respective hosts. Only the sap exudates of the hop-tree (Ptelea trifoliata) inhibited ingestion. Enchenopa binotata nymphs from the population associated with the hop-tree also showed a negative response to these extracts but only at a higher concentration.

Water-soluble quaternary alkaloids are the secondary metabolites of the hop-tree most likely to be present in the extracts used in this study and in the phloem sap of the plant. They also occur in the honeydew of nymphs feeding on this species. Because these compounds are known to be cytotoxic, it is likely that hop-tree E. binotata nymphs possess physiological specializations to detoxify or tolerate them.

\section{Introduction}

Like many phloem-feeding homopterans, the membracids Vanduzeea arquata Say and Enchenopa binotata (Say) have restricted host ranges. Vanduzeea arquata is monophagous, occurring only on the black locust tree (Robinia pseudoacacia L.: Papilionaceae) throughout its range (Funkhouser, 1917). Populations of E. binotata can be found on several species of woody plants in the northeastern United States (including $R$. pseudacacia), but these populations appear to be reproductively isolated and thus represent separate species (Wood, 1980; Guttman et al., 1982; Wood \& Gutt- man, 1983). Some of the species of the $E$. binotata complex utilize several congeneric host species such as Celastrus orbiculatus and C. scandens, Juglans nigra and $J$. cinerea, or several species of Viburnum (Kiss, 1983). Thus, the complex as a whole may be best described as narrowly oligophagous.

Specific host associations of insect populations in the field may be related to discriminatory behaviour and specializations in the individuals. Wood (1980) and Kiss (1983) showed that adult females of the $E$. binotata complex oviposit preferentially on their respective hosts and often die without ovipositing when caged on other plants, including one anothers' host species. The purpose of the present 
study was to extend the investigation of host-discrimination to the feeding behavior of the nymphs and to compare the discriminatory capacities of $V$. arquata and E. binotata, considering their different degrees of host specificity in the field.

Host-selection behavior and specific host associations are known often to be mediated or influenced by the responses of herbivorous insects to plant secondary metabolites. These compounds can act both as behavioral stimuli and as physiological determinants of host-suitability. A number of studies have shown that secondary compounds can influence the behavior of phloem-feeding homopterans such as aphids (eg. Mittler \& Dadd, 1965; Arn \& Cleer, 1971; Dreyer \& Jones, 1981) and delphacids (Fisk, 1980; Yoshihara et al., 1979). In particular, the presence of plant extracts or specific secondary compounds in artificial diets can decrease ingestion and reduce fecundity and survivorship, even of homopterans which are specialists on plants containing those compounds. In some cases this apparent contradiction may be resolved by the fact that the compounds are not present in the phloem sap and thus not ingested although they may serve as behavioral cues to the insect which encounters them while probing through peripheral tissues to the phloem. Other evidence suggests, however, that potentially toxic secondary compounds may be ingested by some phloem feeders (Camm et al., 1976; Wink et al. 1982). In the present study the influence of plant chemistry on the hostselection behavior of nymphs of $E$. binotata and $V$. arquata was examined by means of discrimination experiments utilizing twigs, whole-leaf extracts and sap exudates of host and non-host plants. The experiments were designed to distinguish between effects of the extracts on probing and on ingestion. This appears to be the first such study of membracid host selection and the first to examine the effect of sap exudates on homopteran feeding behavior.

\section{Materials and methods}

The membracids and plant materials were collected from several field sites in the vicinity of Ann Arbor, Michigan (Washtenaw Co.) in July and August of 1981 and 1982. Individuals from E. binotata populations associated with Ptelea trifoliata, the bittersweets, Celastrus scandens L. and C. orbicula- tus Thunb. (Celastraceae) and Robinia pseudoacacia were used; they are here referred to as the Hoptree- $E$. binotata, the Bittersweet $E$. binotata and the Locust-E. binotata, respectively, because they have not yet been described as separate species. Enchenopa binotata nymphs were tested for their discrimination between twigs and extracts of their own and one anothers' hosts, and between twigs of their respective hosts and the bur oak, Quercus macrocarpa Michx. (Fagaceae), which is not commonly reported as a host for $E$. binotata. Individuals of $V$. arquata were collected from black locust and tested for their discrimination between that species and the three non-host species above.

All discrimination experiments consisted of pairwise choice tests. Nymphs were released into the experimental chambers and left undisturbed for $24 \mathrm{~h}$. The proportion of nymphs settling on the host versus non-host twig or on the plant extract versus the control solution was then recorded and the Matched Pairs Sign Test (MPST) was used to determine significance levels. Nymphs were used in preference to adults because they settled to feed more readily under these experimental conditions. Nevertheless, some nymphs failed to settle in each trial, with the result that final sample sizes are variable. Separate trials were conducted using newly hatched individuals ('hatchlings') which had been removed from their natal host plants prior to beginning to feed and older (3rd-5th instar) individuals collected from host plants in the field.

Preparation of plant materials (twigs, leaf extracts, sap exudates). Discrimination experiments involving twigs were conducted indoors on freshly collected twigs whose severed ends were kept submerged in tap water. Such severed twigs remained green and continued to put out new growth for up to 2-3 weeks and nymphs could be maintained on them from hatching to maturity.

For experiments using whole-leaf extracts, freshly collected, mature leaves were freeze-dried, crushed and extracted in distilled water at just below boiling temperatures for one half hour. The ' $1 \%$ ' solutions used in the feeding experiments were obtained by extracting $1 \mathrm{~g}$ (dry weight) of plant material per $100 \mathrm{ml}$ of water.

'Air-sap' exudates were obtained by forcing fluids from young twigs by means of air pressure. Fresh twigs were cut into segments approximately 8 
$\mathrm{cm}$ long and connected by means of a tight-fitting, flexible plastic tube to a laboratory air spigot. The distal ends of the twigs were immersed in distilled water, to a depth of approximately $1 \mathrm{~cm}$. When the air was turned on, gas and liquid exuded from the distal ends of the twigs, eventually turning the water turbid and frothy. The concentration of air-sap used in the feeding experiments represents the exudate forced from 20 twig segments, each blown out for two minutes, collected in $1 \mathrm{ml}$ of water.

'EDTA-sap' exudates were obtained by means of an ethylenediaminotetraacetic acid (EDTA)-enhanced exudation technique modified from that described by King \& Zeevaart(1974) and Costello et al. (1982). The petioles of freshly collected, mature leaves were recut under an $80 \mathrm{mM}$ EDTA solution (brought to $\mathrm{pH} 7$ with concentrated $\mathrm{KOH}$ ). The leaves were placed upright in a beaker of the EDTA solution, with their petioles immersed to a depth of approximately $2 \mathrm{~cm}$, for two hours. (The EDTA treatment prevents the formation of callous tissue in the severed sieve tube elements, allowing exudation to continue over a long period of time.) The leaves were then rinsed in cold tap water and placed upright with petioles immersed in distilled water for $24 \mathrm{~h}$. The leaves and beaker were enclosed in a sealed plastic bag to reduce water loss through transpiration. After $24 \mathrm{~h}$ the water in the beaker was freeze-dried, leaving a small quantity of water-soluble, mostly crystalline residue. The ' $1 \%$ ' and ' $5 \%$ ' solutions used in the feeding experiments contained $0.01 \mathrm{~g}$ and $0.05 \mathrm{~g}$ of this residue, respectively, per 1 $\mathrm{ml}$ of distilled water.

Discrimination experiments. In trials using whole twigs, groups of five nymphs were placed on the floor of an experimental chamber between two twigs which were placed in contact with one another to facilitate movement of the nymphs between them.

Experiments utilizing plant extracts (whole-leaf extracts and sap exudates) were carried out in chambers constructed from $35 \mathrm{~mm}$-diameter plastic Petri dishes and Parafilm sheets. The two types of chambers used are shown diagrammatically in Fig. 1 (A \& B). In the 'single-layer' chamber (Fig. 1A) designed to test the influence of plant extracts on ingestion behavior, a Parafilm sachet was divided into two sealed compartments, one containing the plant extract in a 5\% sucrose solution and

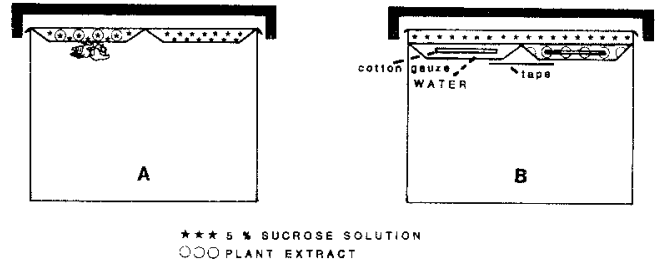

Fig. I. Design of experimental chambers used in pairwise choice tests involving plant extracts: (A) 'Single-layer' experiments testing feeding behavior; (B) 'Double-layer' experiments testing probing behavior. (Proportions not to scale).

the other (control) containing the sucrose solution alone. The nymphs probed through the Parafilm to ingest either of these two solutions. In the "doublelayer' chamber (Fig. 1B), designed to test the influence of extracts on probing behavior, nymphs probed through a Parafilm compartment containing a layer of thin cotton gauze soaked in either the test extract (without added sucrose) or a distilled water control before reaching a second layer consisting of a pure 5\% sucrose solution. This design was intended to simulate more closely the natural condition, in which the nymphs' stylets must penetrate peripheral plant tissue layers to reach the sucrose-rich phloem sap on which they feed. In several trials different food colorings were added to each solution and later observed in the honeydew on the floor of the chamber. In this way it was shown that the nymphs did penetrate through the leaf extracts and water controls to ingest the sucrose solution. In the double-layer chambers it was necessary to cover the narrow strip of compressed Parafilm which separated the paired test compartments with cellophane tape to prevent nymphs from settling primarily on that region.

Each chamber was oriented such that the Parafilm sachet formed the roof, and was illuminated from above by a 40 or 75 watt lightbulb. This encouraged the positively phototropic, negatively geotropic nymphs to remain in contact with the sachet and probe into it.

Leaf extracts, air-sap exudates and EDTA-sap exudates from the black locust, the hop-tree and the bittersweets were used in the single-layer experiments. Dilute $\mathrm{KOH}$ and $\mathrm{HCl}$ were used to standardize the $\mathrm{pH}$ of these extracts and their respective control solutions: $\mathrm{pH}=5.5$ for leaf extracts, which are naturally acidic, and $\mathrm{pH}=7.5$ for sap exudates, 
to reflect the slightly alkaline nature of phloem sap (Canny 1973). Only leaf extracts were used in the double-layer experiments. In each trial, one to five nymphs were placed into the chamber between the paired compartments; the locations of all nymphs whose stylets were visibly embedded in the Parafilm were recorded $24 \mathrm{~h}$ later. In the single-layer experiments it was proposed that nymphs would probe into the two solutions at random but that the length of time they spent feeding would depend on the presence of feeding inhibitors or stimulants (to counter or supplement the stimulatory effect of the added sucrose). In the double-layer experiments it was proposed that the probability that nymphs would continue probing through the test (outer) layer until they reached the sucrose (inner) layer would depend on the presence of probing stimulants or inhibitors in the test solution.

\section{Results}

Discrimination experiments. The nymphs showed a significant preference for the twigs of their respective host species whether or not they had fed on their natal host plants prior to testing (Table 1). However, in each case a small proportion of $E$. binotata nymphs did settle on non-host twigs, including those of the bur oak. By contrast, all nymphs of $V$. arquata showed absolute discrimination, settling only on the twigs of their host, the black locust.
The results of the single-layer experiments using plant extracts are shown in Table 2A. Ingestion by nymphs of $V$. arquata was significantly inhibited by the leaf extracts of all three plant species and stimulated by the air-sap of their host, the black locust. Surprisingly, these nymphs also-responded positively to the air-sap of the bittersweets yet negatively to the EDTA-sap.

None of the extracts of the black locust or the bittersweets significantly affected settling by any of the $E$. binotat $a$ individuals in the single-layer experiments. The Hop-tree-E. binotata differed from the others in their response to the hop-tree extracts: while nymphs of the Bittersweet-E. binotata and the Locust- $E$. binotata discriminated strongly against all types of hop-tree extracts, the Hop-tree$E$. binotata individuals showed a relatively weak negative response to this leaf extract and none to the air-sap or EDTA-sap. However, the Hop-treeE. binotata nymphs did avoid a more concentrated solution of the hop-tree EDTA-sap, suggesting that their differential response to hop-tree leaf extract and sap exudate was due to quantitative, rather than qualitative, differences between the samples.

In contrast to their inhibitory effects on ingestion, the leaf extracts had a positive or neutral effect on probing behavior (Table $2 \mathrm{~B}$ ). With the exception of a moderately negative response by the Hoptree-E. binotata nymphs to the bittersweets $(\mathrm{p}<$ 0.05 ) there was no evidence for probing inhibitors in the leaf extracts from any of the three plant species, including the hop-tree. The majority of the

Table 1. Feeding-discrimination in nymphs of E. binotata and V. arquata: experiments using whole twigs.

Total number of nymphs settling on twigs of hosts vs. non-hosts

\begin{tabular}{|c|c|c|c|c|c|c|c|c|}
\hline \multirow{4}{*}{$\begin{array}{l}\text { Hatchlings } \\
\text { Older nymphs }\end{array}$} & \multicolumn{2}{|c|}{ Hop-Tree-E. binotata } & \multicolumn{2}{|c|}{$\frac{\text { Bittersweet- } E \text {. binotata }}{\text { On twigs of: }}$} & \multicolumn{2}{|c|}{ Locust-E. binotata } & \multicolumn{2}{|c|}{ V. arquata } \\
\hline & $\begin{array}{l}\text { On twigs of: } \\
\text { hop-tree }\end{array}$ & $\begin{array}{l}\text { bitter- } \\
\text { sweets }\end{array}$ & \multicolumn{2}{|c|}{$\begin{array}{l}\text { On twigs or: } \\
\text { bitter- hop-tree } \\
\text { sweets }\end{array}$} & $\begin{array}{l}\text { On twi } \\
\text { black } \\
\text { locust }\end{array}$ & hop-tree & $\begin{array}{l}\text { On tw } \\
\text { black } \\
\text { locust }\end{array}$ & hop-tree \\
\hline & 18 & 4 & 35 & 5 & 21 & 0 & & \\
\hline & 61 & 6 & 13 & 2 & 75 & 7 & 71 & 0 \\
\hline & hop-tree & $\begin{array}{l}\text { black } \\
\text { locust }\end{array}$ & $\begin{array}{l}\text { bitter- } \\
\text { sweets }\end{array}$ & $\begin{array}{l}\text { black } \\
\text { locust }\end{array}$ & $\begin{array}{l}\text { black } \\
\text { locust }\end{array}$ & $\begin{array}{l}\text { bitter- } \\
\text { sweets }\end{array}$ & $\begin{array}{l}\text { black } \\
\text { locust }\end{array}$ & $\begin{array}{l}\text { bitter- } \\
\text { sweets }\end{array}$ \\
\hline Hatchlings & 47 & 13 & 45 & 12 & 25 & 4 & & \\
\hline \multirow[t]{2}{*}{ Older nymphs } & 58 & 5 & 30 & 10 & 66 & 4 & 33 & 0 \\
\hline & hop-tree & bur oak & $\begin{array}{l}\text { bitter- } \\
\text { sweets }\end{array}$ & bur oak & $\begin{array}{l}\text { black } \\
\text { locust }\end{array}$ & bur oak & $\begin{array}{l}\text { black } \\
\text { locust }\end{array}$ & bur oak \\
\hline Older nymphs & 62 & 16 & 36 & 7 & 23 & 10 & 18 & 0 \\
\hline
\end{tabular}


Table 2. Discrimination of plant extracts by E. binotata and V. arquata: (A) single-layer experiments (effect on ingestion); (B) double-layer experiments (effect on probing).

\begin{tabular}{|c|c|c|c|c|}
\hline & \multicolumn{4}{|c|}{ Number of nymphs choosing extract/Number choosing control } \\
\hline & $\begin{array}{l}\text { Hop-tree } \\
\text { E. binotata }\end{array}$ & $\begin{array}{l}\text { Bittersweet- } \\
\text { E. binotata }\end{array}$ & $\begin{array}{l}\text { Locust- } \\
\text { E. binotata }\end{array}$ & V. arquata \\
\hline \multicolumn{5}{|c|}{ (A) Single-layer experiments } \\
\hline \multicolumn{5}{|c|}{ Whole leaf extracts of: } \\
\hline Hop-tree & $10 / 27(-)$ & $5 / 31(--)$ & $2 / 47(--)$ & $3 / 32(-)$ \\
\hline Bittersweets & $10 / 22$ & $8 / 15$ & $9 / 20$ & $12 / 36(-)$ \\
\hline Black Locust & $11 / 11$ & $7 / 15$ & $28 / 20$ & $10 / 36(-)$ \\
\hline \multicolumn{5}{|l|}{ Air-sap exudates of: } \\
\hline Hop-tree & $15 / 24$ & $1 / 24(--)$ & $8 / 45(--)$ & $4 / 9.2(--)$ \\
\hline Bittersweets & $15 / 15$ & $14 / 11$ & $12 / 22$ & $78 / 36(++)$ \\
\hline Black Locust & 4/ 6 & $15 / 10$ & $40 / 43$ & $121 / 36(++)$ \\
\hline \multicolumn{5}{|l|}{ EDTA-sap exudate of: } \\
\hline Hop-tree $(1 \%)$ & $14 / 27$ & $26 / 43(-)$ & $8 / 30(--)$ & $1 / 63(--)$ \\
\hline Hop-tree $(5 \%)$ & $7 / 18(-)$ & $1 / 20(--)$ & $0 / 6(-)$ & $0 / 10(--)$ \\
\hline Bittersweets $(1 \%)$ & $12 / 11$ & $17 / 30$ & $9 / 12$ & $19 / 46(--)$ \\
\hline Black Locust ( $1 \%)$ & $18 / 22$ & $29 / 29$ & $10 / 15$ & $23 / 19$ \\
\hline \multicolumn{5}{|c|}{ (B) Double-layer experiments } \\
\hline \multicolumn{5}{|c|}{ Whole leaf extracts of: } \\
\hline Hop-tree & $28 / 4(++)$ & $10 / 12$ & 4/ 7 & $15 / 14$ \\
\hline Bittersweets & $7 / 18(-)$ & $25 / 10(+)$ & $16 / 18$ & $16 / 20$ \\
\hline Black Locust & $22 / 18$ & $14 / 8$ & $29 / 20$ & $34 / 0(++)$ \\
\hline
\end{tabular}

Positive response to extract: $(+) \mathrm{p}<0.05 ;(++) \mathrm{p}<0.01$.

Negative response to extract: $(-) \mathrm{p}<0.05 ;(-) \mathrm{p}<0.01$ (matched pairs sign test).

membracids showed a significant, positive probing response only to the leaf extracts of their respective hosts; however, the Locust-E. binotata nymphs responded somewhat positively to both the bittersweets and black locust leaf extracts.

\section{Discussion}

There is probably little direct selective pressure for discriminatory capacity in the juvenile stages of these membracids because the developmental host is largely selected by the ovipositing females. Nevertheless, they did show a highly significant preference for twigs of their own host species and a similar degree of feeding-specificity has been reported for the nymphs of several other homopteran species with similar life histories (Claridge et al., 1977; Stiling, 1980; Booij, 1982). It may be suggested that these preferences in the juvenile stages exist as an indirect result of selection for specificity in the adults.

The selectivity of individual $E$. binotata nymphs was less than that shown by $V$, arquata nymphs. This difference in individual behavior is consistent with the degree of specificity shown by these membracid species in the field. The diversity of hosts on which the species of the $E$. binotata complex occur may be related to the propensity of these individuals to accept novel hosts, thus increasing the likelihood that offshoot an population would become established on a new host.

Extracts inside Parafilm sachets provide only a fairly poor approximation of the chemical features of living plants. Nevertheless, this technique has provided valuable insights into the influence of plant chemistry on homopteran host-selection behavior. The results presented here confirm and extend those of earlier studies (cf. references cited above) and support the hypothesis that host-specific secondary plant compounds may stimulate probing but inhibit ingestion by homopterans. This observation is consistent with the fact that many such compounds are likely to be encountered, but not ingested, by a phloem-feeder whose stylets do not break peripheral cells while penetrating to the 
phloem. Thus it is important to examine the responses of homopterans to the phloem-sap itself. Although the sap exudates used in this study may not represent pure phloem sap, they should provide a closer approximation of the material normally ingested by a phloem-feeder than do the leaf extracts which have been used in many studies.

Both the air-sap and the EDTA-sap samples from the hop-tree inhibited ingestion, particularly by nymphs associated with other hosts. Kiss (1983) found that nymphs from six different $E$. binotata species could be reared from hatching to adulthood on both the black locust and the bittersweets but only the Hop-tree- $E$. binotata survived on the hoptree. All others showed no sign of feeding and died within a few days of transfer. The results of the present discrimination experiments strongly suggest that these nymphs failed to feed on the hop-tree because its phloem sap contains feeding inhibitors.

of the coumarins and furoquinoline alkaloids which comprise the principal secondary compounds of the hop-tree (Dreyer, 1969; Mitscher et al., $1975 \mathrm{a}, \mathrm{b})$ only one class, the rare quaternary alkaloids, are water-soluble and thus likely to be present in the phloem sap. Thin layer chromatography and ultraviolet spectroscopy indicate the presence of one or more quaternary alkaloids in the hop-tree extracts used in this study and in the honeydew of nymphs feeding on hop-trees (Kiss, 1983). Because these compounds are reported to be cytotoxic (Mitscher et al. 1975a; Rideau et al., 1979) it seems likely that the Hop-tree-E. binotata posess specific physiological adaptations allowing them to detoxify or tolerate these constituents of their host plant. Such adaptations have been demonstrated for a number of herbivorous insects but not yet for any homopteran species.

\section{Résumé}

Comportement de sélection de l'hôte par les larves de Vanduzeea arquata et des espèces du complexe Enchenopa binotata (Homoptera: Membracidae): distinction des pousses saines, des extraits de feuilles et d'exsudats de sève

Les larves de Vanduzeea arquata Say et de 3 membres du complexe Enchenopa binotata Say préfèrent légèrement plus les pousses des espèces de leurs hôtes respectifs dans des choix binaires. Les réponses (alimentation et sondage) des larves à des extraits de feuille et à des exsudats de sève d'espèces de plantes hôtes ou non ont été examinées avec des sachets à couche simple ou double de parafilm. Les extraits de feuille de plante hôte stimulaient le sondage par beaucoup de larves. Les extraits de feuille et de sève de Ptelea trifoliata (Rutacées) inhibaient la prise de nourriture des larves de toutes les espèces, mais l'effet dissuadant était moins prononcé sur les larves des espèces d'Enchenopa associées à cet arbre que sur les autres. La présence d'alcaloïdes quaternaires dans le phloem de cet arbre peut dissuader les autres larves de membracides de s'alimenter sur cette essence, mais ces substances ont été décelées dans les larves d'Enchenopa et dans leur miellat. Des glucosides flavonoïdes, présents dans les extraits de feuille et les exsudats de sèvé de Robinia pseudoacacia (Fabacées) et de Celastrus scandens et $C$. orbiculatus (Célastracées), n'ont pas modifié significativement le comportement alimentaire des larves d'Enchenopa, mais peuvent avoir influencé celui des larves de $V$. arquata. Les larves d'Enchenopa présentaient une plus faible aptitude que les larves de $V$. arquata à choisir leur hôte; leur tolérance relative pour des espèces non hôtes peut être liée à la spéciation en fonction de la filiation de végétaux qui semble avoir eu lieu dans ce groupe.

\section{References}

Arn, H. \& J. S. Cleer, 1971. A double-label choice-test for the simultaneous determination of diet preference and ingestion by the aphid Amphorophora agathonica. Ent. exp. \& appl. 14: 377-387.

Booij, C. J. H., 1982. Biosystematics of the Muellerianella complex (Homoptera: Delaphacidae): host-plants, habitats and phenology. Ecol. Ent. 7: 9-18.

Camm, E. L., C. K. Watt \& G. H. N. Towers, 1976. An assessment of the role of furanocoumarins in Heracleum lanatum. Can. J. Bot. 54: 2562-2566.

Canny, M. J., 1973. Phloem Translocation. Cambridge University Press, Cambridge: 301 pp.

Claridge, M. F., W. J. Reynolds \& M. R. Wilson, 1977. Oviposition behavior and food plant discrimination in leafhoppers of the genus Oncopsis. Ecol. Ent. 2: 19-25.

Costello, L. R., J. H. Bassham \& M. Calvin, 1982. Enhancement of phloem exudation from Fraxinus uhdei Wenz. Plant Physiol. 69: 77-82.

Dreyer, D. L., 1969. Coumarins and alkaloids of the genus Ptelea. Phytochem. 8: 1013-1020.

Dreyer, D. L. \& K. C. Jones, 1981. Feeding deterrency of flavo- 
noids and related phenolics towards Schizaphis graminum and Myzus persicae: aphid feeding deterrents in wheat. Phytochem. 20: 2489-2493.

Fisk, J., 1980. Effects of HCN, phenolic acids and related compounds in Sorghum bicolor on the feeding behaviour of the planthopper Peregrinus maidis. Entomol. exp. appl. 27: 211-222.

Funkhouser, W. D., 1917. Biology of the membracidae of the Cayuga Lake Basin. Cornell University Agricultural Experimental Station Memoir 11: 177-445.

Guttman, S. I., T. K. Wood \& A. A. Karlin, 1981. Genetic differentiation along host plant lines in the sympatric Enchenopa binotata Say complex (Homoptera: Membracidae). Evolution 35(2): 205-217.

King, R. W. \& J. A. D. Zeevaart, 1974. Enhancement of phloem exudation from cut petioles by chelating agents. Pl. Physiol. 53: $96-103$

Kiss, A., 1983. Host-specificity and host-selection behavior in the Enchenopa binotata species complex (Homoptera: Membracidae). PhD. Dissertation, The University of Michigan, Ann Arbor.

Mitscher, L. A., S. B. Mohinder, G. W. Clark \& J. L. Beal, 1975a. Antimicrobial agents from higher plants. The quaternary alkaloids of Ptelea trifoliata. Lloydia 38(2): 109-116.

Mitscher, L. A., S. B. Mohinder, G. W. Clark \& J. L. Beal, 1975b. Antimicrobial agents from higher plants. The antimicrobially inactive components of Ptelea trifoliata. Lloydia 38(2): $117-124$.
Mittler, T. E. \& R. H. Dadd, 1965. Differences in the probing responses of Myzus persicae elicited by different feeding solutions behind a parafilm membrane. Entomol. exp. appl. 8: $107-122$.

Rideau, M., C. Verchere, P. Hibon, J. C. Chenieux, P. Maupas \& C. Viel, 1979. Alcaloides dihydrofuroquinoleiques de quelques Rutaceae: isolement, structure, proprietes biologiques. Phytochem. 18: 155-159.

Stiling, P. D., 1980. Host plant specificity, oviposition behavior and egg parasitism in some leafhoppers of the genus Eupteryx (Hemiptera: Homoptera: Cicadellidae). Ecol. Ent. 5(1): 76-86.

Wink, M., T. Hartmann, L. Witte \& J. Rheinheimer, 1982. Interrelationship between quinolizidine alkaloid producing legumes and infesting insects: exploitation of the alkaloidcontaining phloem sap of Cytisus scoparius by the Broom Aphid Aphis cytisorum. Z. Naturforsch. 37c: 1081-1086.

Wood, T. K., 1980. Divergence in the Enchenopa binotata Say complex (Homoptera: Membracidae) affected by host plant adaptation. Evolution 34: 147-160.

Wood, T. K. \& S. I. Guttman, 1983. Enchenopa binotata complex: sympatric speciation? Science 220: 310-31 I.

Yoshihara, T., K. Sogawa, M. D. Pathak, B. O. Juliano \& S. Sakamura, 1979. Soluble silicic acid as a sucking inhibitory substance in rice against the brown planthopper (Delphacidae: Homoptera). Entomol. exp. appl. 26: 314-322.

Accepted: May 22, 1984 